\title{
PENGATURAN HUKUM SERTIFIKAT HAK ATAS MEREK SEBAGAI JAMINAN FIDUSIA DALAM PROSES PENGAJUAN KREDIT DI PERBANKAN BERDASARKAN UNDANG-UNDANG NOMOR 20 TAHUN 2016
}

\author{
Oleh: \\ Made Bagus Satria Yudistira ${ }^{1}$
}

\begin{abstract}
United Nations Commission on Intellectual Trade Law (UNCITRAL) in a conference held on $39^{\text {th }}$ round in 2006, this round brought to the result of intellectual properties, specifically on the Trademarks that has been the source of bank financing. Then the things that to be discussed regarding to the legal arrangements of the rights certificate on the trademark as fiduciary assurance in the process of application for bank credit and also the ideal form provisions of the trademark as an object that used as an assurance object. The purpose of this writing is to find the explication of the rule of law concerning about the rights provision to the trademark as a fiduciary assurance after the issuance of the constitutions number 20 of 2016 about trademark and geographical indications, because in that constitution there was nothing firm as it stated on the article that related to the rights of the trademark as fiduciary assurance or the norm is blurred and implicitly stated that the rights of the trademark can be used as an object of fiduciary assurance. Besides that there was also the non-law factor and the bank policy that complicates the process in banking. Nevertheless there is a legal basis that arranged by the constitutions number 42 of 1999 regarding the fiduciary assurance and the code of civil law concerning the elements of the trademark that can be used as fiduciary assurance in the process of credit application.
\end{abstract}

Keywords: Trademarks, Fiduciary Assurance, and The Rights of Trademark

\begin{abstract}
Abstrak
United Nations Comission on Intellectual Trade Law ( UNCITRAL) dalam pertemuan yang diselenggarakan pada putaran ke 39 yaitu pada tahun 2006, putaran in menghasilkan kekayaan intelektual, khususnya Merek telah menjadi sumber pembiayaan Perbankan. Maka yang perlu dibahas mengenai Pengaturan Hukum sertifikat Hak atas Merek sebagai jaminan Fidusia dalam proses pengajuan kredit di perbankan serta ketentuan wujud ideal dari merek sebagai benda yang dijadikan obyek jaminan. Tujuan dari Penulisan adalah mencari kejelasan aturan hukum mengenai ketentuan Hak atas merek sebagai jaminan fidusia setelah diterbitkannya Undang-undang no 20 tahun 2016 tentang Merek dan Indikasi Geografis, karena di dalam Undang-undang tersebut tidak menyatakan dengan tegas Pasal yang berkaitan dengan hak Merek sebagai jaminan fidusia atau norma

1 Program Studi Magister Ilmu Hukum, Fakultas Hukum, Universitas Udayana, Denpasar Bali. Email bagusyudistira34@yahoo.com.
\end{abstract}


kabur yang tidak secara tegas menyatakan Hak atas Merek dapat dijadikan objek sebagai Jaminan fidusia. Di samping itu juga terdapat faktor non-hukum serta kebijakan Bank yang mempersulit prosesnya di perbankan. Walaupun demikian sesungguhnya terdapat dasar hukum yang diatur oleh Undang-undang no 42 tahun 1999 tentang jaminan Fidusia dan Kitab Undang-undang hukum Perdata mengenai unsur-unsur Merek bahwa dapat dijadikan sebagai jaminan fidusia dalam proses pengajuan kredit.

\section{Kata kunci : Merek, Jaminan Fidusia, Hak Atas Merek}

\section{PENDAHULUAN}

World trade organization (selanjutnya disebut sebagai WTO) merupakan suatu organisasi yang bergerak di bidang perdagangan internasional khususnya hak atas kekayaan intelektual yang diakomodasikan oleh Trade Related Aspect of Intellectual Property Rights yang mulai memberikan perhatian bagi masyarakat internasional sebagai sumber pembiayaan. ${ }^{2}$ Perkembangan masyarakat global menjadikan HAKI sebagai akses untuk mendapatkan kredit perbankan secara internasional. United Nations Comission on Intellectual Trade Law dalam pertemuan yang diselenggarakan pada bagian ke-39 yaitu pada tahun 2006, pertemuan ini menghasilkan hak kekayaan intelektual seperti (patent, cipta, copryright and trademark) yang dapat dijadikan sumber pembiayaan Perbankan. $^{3} \quad$ Menjadikan HAKI sebagai jaminan hutang kini semakin

2 Venantia Sri Hadiarianti, 2015, Memahami Hukum Atas Karya Intelektual, Grafindo, Jakarta, hlm 1

3 Sri Mulyani, Pengembangan Kekayaan Hak Intelektual Sebagai Collateral (agunan) untuk Mendapatkan Kredit Perbankan di Indonesia, Jurnal Fakultas Hukum UNTAG, 2012, Semarang, hlm 569 diakui sebagai prospek yang menarik. ${ }^{4}$ Termasuk salah satunya adalah Hak atas Merek.

Benda yang dimiliki tidak hanya bersifat materil tetapi juga bersifat inmateriil juga perlu dilindungi. Misalnya buah pemikiran yang berhasil menemukan penemuan baru. Inilah yang disebut Hak Kekayaan Intelektual (Intellectual Property Right). Penciptaan hak milikintelektual membutuhkan banyak waktu. selain keahlian, bakat, hasil pemikiran, pekerjaan dan juga materi yang dikeluarkan dalam prosesnya .5 Pada Tahun 2016 telah dikeluarkan Undangundang tentang Merek dan Indikasi Geografis, maka perlu diketahui apakah dalam penerbitan undang-undang ini telah mengakomodir jaminan fidusia dengan jaminan berupa sertifikat Hak atas Merek. Hal ini berarti di dalam undang-undang Nomor 20 tahun 2016 masih belum jelas mengatur Hak atas Merek dapat dijadikan sebagai Jaminan di Perbankan, walaupun terdapat

4 Andrea Tosato, Security Interest Over Intellectual Property, Journal of Intellectual Property Law \& Practice vol. 6 No.2,2010, hlm.93-104

5 Sudargo Gautama, 1990, Segi-segi Hukum Milik Intelektual, Eresco, Bandung, hlm 6 
ketentuan Hukum yang menyatakan unsur-unsur dari suatu Merek dapat dijadikan agunan perbankan maka tentu terdapat norma kabur terkait pengakuan yuridis mengenai sertifikat Hak atas Merek sebagai Jaminan Fidusia dalam proses pengajuan kredit dalam Undang-Undang No. 20 Tahun 2016.

Berdasarkan uraian Latar Belakang yang telah dijelaskan di atas maka permasalahan yang dapat dikemukakan adalah sebagai berikut:

1. Bagaimanakah Pengaturan

Hukum terhadap Hak atas Merek sebagai Jaminan Fidusia dalam Proses Pengajuan Kredit berdasarkan Undang-undang No 20 tahun 2016 tentang Hak Merek dan Indikasi Geografis ?

2. Bagaimanakah Ketentuan Hukum yang mengatur Wujud ideal dari Merek Sebagai Benda untuk dapat dijadikan sebagai Objek Jaminan Fidusia di Perbankan?

Sebelum penelitian ini, ada beberapa penelitian sebelumnya (originalitas penelitian), yakni :

1. Sri Mulyani, Realitias Pengakuan Hukum terhadap Hak atas Merek Sebagai Jaminan Fidusia Pada Praktek Perbankan di Indonesia, Jurnal Fakultas Hukum UNTAG, Vol. 11 No. 2 edisi April 2014, hal $135-148$

2. Susilowardhani, Problematik Yuridis Objek Jaminan Berupa Hak Merek, Tesis MH
Universitas Sebelas Maret, 2015

3. Bekartini Caroline, Pengkualifikasian Merek Sebagai Benda Untuk Dapat Dijadikan Objek Jaminan, Jurnal Wawasan Hukum Vol. 34 No. 1 Februari 2016, 102-113

Tujuan khusus dari jurnal ini adalah mengetahui pengaturan yuridis yang berkaitan dengan Sertifikat Hak atas Merek yang dapat digunakan sebagai jaminan Fidusia pada lembaga Perbankan setelah diterbitkannya undang-undang No.20 Tahun 2016 mengenai Merek dan Indikasi Geografis.

\section{METODE PENELITIAN}

Penelitian ini merupakan proses menentukan aturan-aturan, asas-asas Hukum, Doktrin maupun prinsip Hukum sebagai dasar menjawab permasalahanyang dihadapi.Penelitian ini termasuk dalam ranah kajian metode yuridis normative. Metode yuridis normative adalah teknik penelitian dengan mencermati atau mempelajari data-data, dokumen, kajian terhadap peraturan, norma ataupun asas yang tercantum dalam peraturan tersebut. Deskriptif merupakan jenis Penulisan yang menghasilkan gambaran selengkap-lengkapnya yang berkaitan dengan permasalahan yang sedang diteliti.

Landasan teori yang digunakan di dalam penelitian ini yaitu Teori Hukum Murni yang dipelopori oleh Hans Kelsen. Teori ini mendasarkan 
kepada Hukum Positif yang bertujuan untuk mengkonsepsikan suatu Hukum yang digunakan sebagai landasan yang dibuat dan memperoleh pengakuan dari Negara. ${ }^{6}$.selanjutnya teori ini akan dihubungkan dengan Peraturan Perundang-undangan Nomor 42 tahun 1999 mengenai jaminan Fidusia dan juga Undang-undang No. 20 tahun 2016 tentang Merek dan Indikasi Geografis sebagai hukum positif di Masyarakat.

III HASIL DAN PEMBAHASAN

3.1. Pengaturan Hukum Hak Atas Merek sebagai Jaminan Fidusia Berdasarkan Undangundang no 20 tahun 2016

Mengingat Hak atas Merek merupakan suatu benda tidak berwujud maka hak atas merek dapat dikatakan sebagai objek hak jaminan kebendaan. Adapun ciri- ciri khas dari sifat kebendaan dari Jaminan Kebendaan yaitu sebagai berikut $:^{7}$

1. Memiliki hubungan secara langsung dengan benda tertentu yang dikuasai oleh Debitur;

2. Sifat dari kebendaan yang bisa dipertahankan haknya maupun dialihkan kepada Pihak tertentu.

3. Memiliki sifat Droit de suite, yang berarti hak tersebut selalu melekat pada bendanya di tangan milik siapa pun berada;

6 Daji Darmodiahrjo dan Sidarta, 2008, Pokok - pokok Filsafat Hukum, Gramedia Pustaka Utama, Jakarta, hlm. 115

7 J Satrio,2002, Hukum Hak Jaminan Kebendaan, Cet.Ke-4 Bandung, Citra Aditya Bakti, hlm 12-13
4. Memiliki kedudukan yang lebih tinggi kepada yang lebih tua;

5. Dapat dialihkan atau dipindah tangankan kepada pihak tertentu/ orang lain;

Berdasarkan sifat khas dari kebendaan di atas, dapat disimpulkan bahwa benda yang melekat pada jaminan kebendaan wajib merupakan suatu benda yang sifatnya dapat dipindah tangankan serta memiliki nilai. Dikaitkan dengan hak atas merek, maka Hak atas merek memiliki unsur ciri-ciri benda pada jaminan kebendaan Hak atas merek dapat dipindah tangankan atau dialihkan. Sebagaimana disebutkan pada Pasal 41 Undang-undang No 20 Tahun 2016 mengenai Merek dan Indikasi Geografis bahwa Hak atas merek dapat dialihkan melalui beberapa cara yaitu :

a) Pewarisan;

b) Wasiat;

c) Wakaf;

d) Hibah;

e) Perjanjian atau

f) Sebab lain yang dibenarkan oleh Undang-undang.

Hak atas merek yang kemudian dijadikan sebagai jaminan maka akan tepat jika hak atas merek diikat dengan pengikatan jaminan berupa fidusia. Bahwasanya Fidusia adalah suatu proses pengikatan Jaminan yang juga berlaku menurut hukum di Indonesia selain dari hak tanggungan, gadai, cessie, dan borgtocht (penjaminan hutang). Jaminan fidusia diatur di 
dalam Peraturan perundang-undangan No.42 tahun 1999 mengenai Jaminan Fidusia. Hakatas merek dapat dikatakan sebagai jaminan fidusia karena sesuai dengan objek dari jaminan fidusia yang salah satunya merupakan benda bergerak yang memiliki wujud maupun yang tidak memiliki wujud ( Pasal 2 di dalam undang-undang No 42 tahun 1999). Di samping Proses melalui fidusia juga terdapat proses melalui gadai sebagai hak dari jaminan dan objeknya merupakan benda tidak bergerak. Namun benda bergerak yang digadaikan biasanya harus berbentuk benda bergerak yang berwujud. Hal tersebut kemudian juga menjadi pertimbangan digunakannya fidusia sebagai hak jaminan yang tepat bagi hak atas merek di Indonesia.

Jaminan Fidusia telah diterapkan di Negara Indonesia sejak jaman Belanda yang merupakan salah satu jaminan yang dibentuk dari yurisprudensi. Selanjutnya dalam perkembangannya Jaminan ini semakin popular digunakan oleh masyarakat sebagai sumber pembiayaan yang mencakup berbagai macam transaksi termasuk transaksi Utang piutang karena melalui proses yang dianggap praktis dan cepat, akan tetapi kelemahannya tidak ada jaminan kepastian secara yuridis. Lembaga jaminan fidusia memberikan kesempatan kepada pemberi fidusia untuk tetap bisa menggunakan benda yang menjadi jaminan, sehingga pemberi fidusia akan dapat terus melakukan berbagai macam, aktifitas atau kegiatannya dari proses fidusia tersebut. Lembaga fidusia pada awal berdirinya tidak seperti saat ini dimana objek fidusia terbatas pada benda bergerak yang berwujud saja seperti misalnya peralatan. Kemudian dalam perkembangannya objek jaminan tersebut ruang lingkupnya sudah mencakup termasuk benda yang tidak berwujud, juga benda yang tidak bergerak. $^{8}$

Pada awalnya lembaga fidusia timbul karena ketentuan undangundang yang sebelumnya mengatur tentang gadai, kemudian dalam perkembangannya lembaga gadai dianggap banyak kekurangan yang kurang menjamin kesejahteraan masyarakat serta belum cukup untuk memenuhi kebutuhan orang banyak. Kelemahan Lembaga Gadai yang paling utama adalah benda yang dijaminkan harus diserahkan kepada penerima Gadai padahal justru benda tersebut penting bagi kegiatan pemberi Gadai. ${ }^{9}$

Kepastian yang tidak jelas secara yuridis mengenai Hak atas merek dapat dijadikan objek jaminan fidusia, tidak ada satu pun Pasal yang menyatakan Hak atas Merek dapat dijadikan sebagai objek jaminan fidusia berbeda dengan Hak atas cipta yang diatur di dalam undangundangnya sebagai objek jaminan Fidusia. Walaupun sesungguhnya

8 Tan Kamelo,2006, Hukum Jaminan Fidusia : Suatu Kebutuhan yang Didambakan (Edisi Revisi), Alumni, Bandung,hlm. 82

$9 \quad$ Ibid, hlm. 57 
undang-undang ini adalah undangundang baru namun tidak berbeda dengan Undang-undang no 15 tahun 2001 juga mengenai merek sebelumnya tidak tercantum dan diatur mengenai penjelasan ini.

Dasar pengaturan yuridis yang lemah dimana tidak diakuinya merek sebagai jaminan fidusia juga dipengaruhi faktor diluar hukum yaitu kebijakan Bank dimana masyarakat perbankan belum mengakui merek sebagai (agunan), adalah collateral faktor ekonomi. Sebagaimana pendapat masyarakat perbankan apabila merek akan dijadikan harus memenuhi fungsi collateral jaminan yaitu adanya kepastian, nilai ekonomi, dan pangsa pasar (marketable).adanya faktor ekonomi dan juga kebijakan dari pihak perbankan juga merupakan salah satu kesulitan yang menghambat merek sebagai jaminan fidusia, kebijakan Bank dalam menilai benda sebagai jaminan yaitu terutama dalam mengukur nilai dari benda tersebut, karena tidak semua merek memiliki nilai ekonomi. Singkatnya hanya merek yang memiliki nilai ekonomi saja yang mampu dipertimbangkan untuk dapat dijadikan sebagai objek jaminan. yang memenuhi syarat untuk dijadikan jaminan utama dalam pembiayaan, yaitu antara lain merek tersebut dapat diperjualbelikan dan mempunyai pasar (markertable). ${ }^{10}$

10 Sri Mulyani, Realita Pengakuan Hukum Terhadap Hak Atas Merek Sebagai Jaminan Fidusia Pada Praktik Perbankan di Indonesia, Jurnal Fakultas Hukum UNTAG, Vol.11 No.2 Edisi April 2014, hlm.147
Berdasarkan dari ketentuan hukum yang ada bahwa terdapat beberapa alasan merek dapat dijadikan sebagai jaminan fidusia. Alasan Merek dapat dijadikan objek jaminan fidusia tersebut sesuai dengan apa yang dikemukakan Sri Soedewi bahwa terdapat beberapa Prinsip yang utama atas jaminan fidusia yaitu : ${ }^{11}$

1. Berdasarkan prosedurnya, penerima fidusia hanya memiliki kapasitas sebagai pemegang sementara jaminan, bukan sebagai penguasa jaminan sebenarnya..

2. Penerima fidusia berhak mengeksekusi barang jaminan setelah adanya kelalaian dari pihak debitur yang tidak melaksanakan kewajibannya .

3. Apabila kewajiban fidusia telah terpenuhi maka objek yang dijadikan jaminan harus diserahkan kepada pemberi fidusia .

4. Apabila hasil dari lelang barang jaminan melebihi nilai dari tunggakan pinjaman debitur maka kelebihan tersebut wajib dikembalikan kepada pemberi fidusia.

Lebih lanjut, suatu penjaminan fidusia harus dilaksanakan dengan memperhatikan ketentuan-ketentuan serta tata cara sebagai berikut :

11 Sri Soedewi Masjchoen Sofwan, 1975, Hukum Jaminan di Indonesia Pokok-Pokok Hukum Jaminan dan Jaminan Perorangan, Liberty, Yogyakarta,hlm.27 
1. Dalam Pasal 6 dalam undangundang nomor 42 tahun 1999 mengenai jaminan Fidusia bahwa jaminan tersebut harus dinyatakan di dalam suatu akta notaries yang memuat :

a) Identitas pihak pemberi dan penerima

b) Data di dalam perjanjian pokok yang dijamin fidusia

c) Penjelasan mengenai benda yang dijadikan objek jaminan fidusia

d) Nilai dari penjaminan, dan

e) Nilai dari benda yang dijadikan objek jaminan fidusia

2. Jaminan Fidusia wajib melalui proses pendaftaran dengan diajukan secara online dengan ditujukan kepada Kantor Pendaftaran Fidusia.

3. Pada penjelasan Pasal 13 undang-undang nomor 42 tahun 1999 mengenai jaminan fidusia, permohonan pendaftaran dari Fidusia wajib mengajukan permohonan dengan melampirkan persyaratan pendaftaran Fidusia yang isinya memuat:

a) Identitas pihak Pemberi dan penerima fidusia

b) Tanggal, nomor akta jaminan Fidusia, nama, tempat kedudukan notaries yang membuat akta jaminan fidusia

c) Data perjanjian pokok yang dijamin fidusia d) Uraian mengenai benda yang menjadi obyek Jaminan Fidusia

e) Nilai penjaminan, dan

f) Nilai benda yang menjadi objek jaminan fidusia

4. Selanjutnya penerimaan pada Permohonan secara lengkap kemudian Kantor Pendaftaran Fidusia akan menyerahkan Sertifikat Jaminan Fidusia kepada penerima Fidusia dengan mencantumkan tanggal yang sama dengan tanggal diterimanya permohonan pada pendaftaran..

Dengan memperhatikan penjabaran diatas, maka dalam hal terjadi penjaminan hak atas merek di Indonesia maka wajib dilakukan pencatatan penjaminannya di kantor pendaftaran jaminan, dalam hal ini Kantor Pendaftaran Fidusia. Kemudian mengenai pencatatan pengalihan di Direktorat Jenderal HAKI di Kementerian Hukum dan Hak Asasi Manusia tidak perlu didaftarkan sebelum terjadinya wanprestasi dari pemilik hak atas merek sebagai penjamin dalam melunasi kewajiban pembayaran hutangnya. Hal tersebut karena adanya pertimbangan bahwa dengan penjaminan, hak kebendaan hak atas merek sebagai objek benda yang dijaminkan tidaklah beralih atau berpindah tangan kepada penerima jaminan. Sementara pengalihan yang wajib dicatatkan di Direktorat Jenderal HAKI Kementerian Hukum dan Hak Asasi Manusia adalah pengalihan yang 
disertai dengan tindakan pemberian atau penyerahan hak kebendaan kepada pihak yang menerima pengalihan. ${ }^{12}$

\subsection{Ketentuan Hukum yang mengatur Wujud Ideal dari} Merek sebagai Jaminan Fidusia.

Konteks Hukum Perdata menjelaskan bahwa yang dimaksud dengan benda adalah segala sesuatu yang dapat dikuasai oleh hak milik, dengan demikian yang dapat menguasai hak milik tersebut adalah subyek hukum, sedangkan hak yang dibebankan tersebut adalah obyek hukum. ${ }^{13}$ penjelasan mengenai ketentuan benda ini diatur pada Buku II KUHPerdata yang berbeda dengan ilmu disiplin di bidang fisika, bahwa dijelaskan Bulan adalah suatu benda (angkasa), dan di dalam penjelasan Hukum Perdata bulan tidak dapat dikatakan suatu benda karena tidak ada yang mampu memilikinya .

Aturan mengenai Hukum Benda dalam Buku II Kitab undang-undang Hukum Perdata menerapkan system Tertutup,yangmengandungpengertian bahwa orang tidak di izinkan untuk mengadakan hak-hak kebendaan selain daripada yang telah menjadi ketentuan dalam undang-undang ini. Di samping itu juga Hukum benda memiliki sifat yang memaksa (dwingendknrecht), artinya harus ditaati, tidak boleh ada

12 Agniya Anggraeni,Op.cit, hlm.19

13 J Satrio, 2002, Hukum Janinan Hak Jaminan Kebendaan, Cet. Ke-4 Bandung, Citra Aditya Bakti, hlm. 12-13 penyimpangan, termasuk menciptakan peraturan baru yang berlawanan dari apa yang telah menjadi aturan yang ditetapkan. KUHPerdata juga menjelaskan bahwa benda tidak semata mata benda yang selalu berwujud atau dapat disentuh/diraba oleh panca indera melainkan juga termasuk benda yang tidak memiliki wujud seperti Hak Kekayaan Intelektual seseorang. Istilah benda juga mencakup segala yang menyangkut dengan harta kekayaan yaitu tagihan/piutang dan segala hak hak lainnya seperti deposito dan bunga pinjaman.

Penjelasan benda secara yuridis menurut Pasal 499 Kitab undang-undang Hukum Perdata yaitu segala sesuatu yang dapat dikuasai atau menjadi objek hak milik. Kesimpulannya bahwa benda dalam penjelasan Undang-undang adalah adanya hak yang melekat pada benda tersebut sehingga dapat dimiliki atau dikuasai. Maka baik benda maupun segala sesuatu yang tidak mampu atau tidak dapat dikuasai maka tidak dapat diartikan sebagai benda, seperti yang dijelaskan dalam ilmu fisika yaitu matahari, bintang dan bulan... ${ }^{14}$

Meskipun penjelasan mengenai benda di dalam Kitab Undang-undang Hukum Perdata meliputi tidak hanya benda memiliki wujud saja, tetapi sebagian besar substansi dari Buku II mengenai benda mengatur benda yang memiliki wujud. Penjelasan

14 Titik Triwulan Tutik,2010,Hukum Perdata dalam Sistem Hukum Nasional, Kencana, Jakarta,hlm.143 
benda yang tidak memiliki wujud tidak dikenal di dalam Hukum Adat, karena sudut pandang masyarakat Indonesia cenderung kepada hal yang bersifat belaka saja (concret denken) berbeda dengan sudut pandang orang barat yang lebih mengedepankan yang ada dalam pikirannya (abstract danke.) ${ }^{15}$ Selain itu, istilah zaak di dalam Kitab Undang-undang Hukum Perdata bukan selalu mengartikan suatu benda, namun dapat berarti hal yang lain seperti seperti : "Perbuatan Hukum" ( Pasal 1792 KUHPerdata), atau "Kepentingan" (Pasal 1354 KUHPerdata), dan tidak terlepas juga berarti "Kenyataan Hukum" (Pasal. 1263 KUHPerdata).

Asas-asas benda sebagai dasar penormaan Hukum Kebendaan, sebagai berikut. ${ }^{16}$

1. Hukum Kebendaan adalah hukum yang memiliki sifat memaksa / tidak dapat di langgar atau disimpangi ( $d$ winget recht). Sebagai Hukum memaksa maka aturan mengenai ketentuan dalam hukum kebendaan yang tercantum pada undang-undang tidak boleh disimpangi atau ditiadakan oleh seorang dan para pihak.

2. Hak Kebendaan dapat dipindah tangankan / dialihkan :

Pada prinsipnya segala hak kebendaan bisa dipindah

15 Wirjojo Prodjodikoro dalam Riduan Syahrani, 1981, Seluk Beluk dan Asas-Asas Hukum Perdata, Alumni, Bandung, hlm.108.

16 Rachmadi Usman,2011, Hukum Kebendaan, Sinar Grafika, Jakarta,hlm. 47 tangankan /serta dapat diberikan kepada siapa pun, dengan syarat yang bersangkutan memiliki kewenangan tersebut.

3. Asas Individualitas (Individualitiet)

Objek Hak Kebendaan yang akan senantiasa barang yang dapat ditentukan dan merupakan suatu kesatuan.

4. Asas Totalitas / Menyeluruh atas Benda (Totaliteit)

Segala Hak Kebendaan akan selalu melekat pada keseluruhan objek bendanya seperti yang tercantum dalam Pasal 500,588,606 KUHP perdata.

5. Asas Tidak Dapat Dipisahkan (Onsplitsbaarheid)

Hak atas segala kebendaan tidak dapat dialihkan sebagian.

6. Asas Prioritas (Prioriteit)

Hak Prioritif merupakan Hak yang mengutamakan terjadinya dimenangkan dengan hak yang akan terjadi kemudian

7. Asas Percampuran (Vermenging) Pada Hak atas Kebendaan yang terbatas pada wewenang nya, hanya mungkin atas pada barang milik pihak lain, dan tidak menutup kemungkinan terhadap barangnya sendiri. Pengaturan serta Perlakuan yang berbeda tentu berbeda pula pada benda yang berbeda. hal tersebut sesuai dengan pembedaan pada benda yang akan membawa konsekuensi atau akibat, serta pengaturan dan perlakuan 
terhadap benda yang berbeda.

8. Asas Publisitas (Publiciteit)

Pada Prinsipnya beralihnya suatu

Hak milik dan pembebanan suatu benda yang tidak bergerak diwajibkan untuk didaftarkan.

Hal ini tentu berbeda dengan benda yang tidak Bergerak yang wajib didaftarkan.

9. Sifat Perjanjiannya sebagai Perjanjian pada kebendaan (Zakelijke Overcenkomst)

Adanya sifat perjanjian dalam setiap pengadaan bahwa hakekatnya dalam setiap Hukum perjanjian memiliki sifat dari asas kebendaan serta di dalam setiap hak yang melekat pada kebendaan serta merta melekat pada sifat dari hukum perjanjian tersebut .

Doktrin dalam Hukum Perdata membedakan macam macam benda salah satunya asas benda yang bergerak. Benda yang bergerak merupakan benda yang berdasarkan sifat aslinya dapat alihkan (Pasal 509 KUHPerdata)benda yang bergerak karena ketentuan Undang-undang adalah hak yang selalu melekat pada benda tersebut. (Pasal 511KUHPerdata), misalnya hak memungut hasil atas benda yang bergerak dan hak mempergunakan atas benda yang bergerak serta termasuk saham-saham Perusahaan.

Benda bergerak tersebut dibedakan atas dua yaitu $:^{17}$

1. Benda yang berdasarkan

17 Titik Triwulan Tutik, op.cit, hlm. 147 "sifatnya" bergerak yang mengandung pengertian bahwa benda tersebut dapat dialihkan dari suatu tempat berpindah ke tempat yang lain seperti sepeda motor, mobil dan yang lain.

2. Benda yang berdasarkan penetapan dari undang-undang sebagai suatu benda yang bergerak adalah segala hak yang timbul di atas bendabenda bergerak. Seperti halnya memetik hasil serta hak untuk mempergunakan, dan hak terhadap bunga yang wajib dibayar selama hidup seseorang.

Penjelasan Pasal 95 pada undang-undang no 20 tahun 2016 tentang hak merek dan Indikasi Geografis menyatakan bahwa sertifikat hak atas merek merupakan bukti hak yang terdaftar. Hak atas merek tersebut adalah benda bergerak yang tidak berwujud. Hal ini didasari atas pengertian dari hak terhadap merek yang salah satu hak eksklusif yang dipersembahkan oleh Negara pada Pemilik Merek yang telah terdaftar. Dengan pengertian tersebut menandakan adanya unsur hak milik dalam hak terhadap merek tersebut.

Sebuah merek wajib didaftarkan. Hal ini disebabkan hak terhadap Merek adalah hak yang khusus dipersembahkan oleh Pemerintah atau Negara untuk Pemilik merek mempergunakan Merek tersebut serta mengizinkan kepada pihak tertentu 
untuk mengelolanya. Oleh karena itu Merek perlu terdaftar pada Direktorat Jenderal Hak Kekayaan Intelektual. Pendaftaran tersebut adalah hal yang penting untuk konsumen, karena dari konsumen merek tersebut dapat memberikan royalty bagi pemiliknya yang tentunya barang yang diperdagangkan memiliki kualitas yang baik. ${ }^{18}$

Sesuatu yang memiliki unsur hak milik dapat dikatakan sebagai benda. Berdasarkan penjelasan Pasal 499 KUHPerdata bahwa kebendaan memiliki arti sebagai tiap-tiap barang dan tiap- tiap hak yang dapat dikuasai oleh hak milik. Dan menurut penjelasan Pasal 570 KUHPerdata juga diartikan sebagai hak untuk menikmati suatu kebendaan dengan leluasa dan dengan kedaulatansepenuhnyabertindakbebas atas kebendaan tersebut, selama tidak bertentangan dengan ketentuan hukum yang telahmenjadi ketetapan penguasa, serta tidak menimbulkan kegaduhan bagi hak-hak pihak tertentu, terhadap itu dengan tidak mengurangi adanya pencabutan hak demi kepentingan umum menurut ketentuan undangundang dengan sejumlah pembayaran untuk ganti rugi. Dengan demikian dapat dikatakan bahwa hak kebendaan itu bersifat mutlak atau absolute..

Hak absolute pada hak atas merek dapat dilihat apabila melihat ke dalam Bab XVIII Ketentuan Pidana dimulai dari Pasal 103 sampai dengan Pasal

18 Suyud Margono, 2011, Hak Milik Industri : Pengaturan dan Praktek di Indonesia, Ghalia Indonesia, Bogor,hlm. 79
105 Undang-undang No 20 tahun 2016. Hal ini merupakan tanda adanya hak absolute dalam hak atas merek karena dalam hal terjadinya pelanggaran, hak atas merek dapat dipertahankan dari pihak mana pun yang melanggarnya. Selain itu rumusan dalam Bab XVIII tersebut menunjukkan adanya tanda sifat drout de suite yang melekat dalam hak atas merek, sebab dimana pun hak atas merek dipergunakan dan oleh siapa pun, tetap saja pemilik hak atas merek mempunyai hak atas hak atas mereknya dan oleh karena itu ia berhak menuntut pihak lain yang mempergunakan hak atas merek yang dimilikinya tanpa persetujuannya terlebih dahulu. ${ }^{19}$

\section{KESIMPULAN}

1. Pengaturan hukum terhadap Hak atas Merek sebagai jaminan fidusia dalam proses pengajuan kredit berdasarkan Undangundang No 20 tahun 2016 mengenai hak atas merek dan Indikasi Geografis kurang jelas atau kabur karena tidak ada satu pun Pasal yang menyatakan Hak atas Merek dapat dijadikan sebagai objek jaminan fidusia, sedangkan di dalam Pasal 41 disebutkan bahwa Hak atas Merek dapat dialihkan salah satunya karena perjanjian

19 Agniya Anggreni, Hak Atas Merek sebagai Jaminan Perusahaan : Dalam Pelaksanaannya di Indonesia, Amerika Serikat, China, Inggris dan Singapura, "Tesis FH UI", (Jakarta,2015)hlm.27 
dengan syarat bahwa perjanjian tersebut setelah dialihkan harus dimohonkan pencatatannya kepada menteri dan kepada direktorat Jenderal HAKI, dan yang disebutkan di Pasal ini cukup jelas menyebutkan bahwa hak terhadap Merek tersebut dapat diajukan ke dalam proses perjanjian termasuk perjanjian kredit sebagai jaminan fidusia di perbankan.

2. Berdasarkan ketentuan Hukum yang mengatur wujud ideal dari Merek bahwa Merek adalah benda bergerak yang tidak memiliki wujud yang di dalam ketentuan juga sebagai objek jaminan fidusia Karena Merek merupakan Hak Atas Kekayaan Intelektual dapat dikategorikan benda. Dalam penjelasan Pasal 499 sampai dengan Pasal 505 KUHPerdata menyebutkan bahwa kebendaan adalah tiaptiap barang dan tiap-tiap hak yang dapat dikuasai oleh hak milik, serta dalam penjelasan Pasal 503,504, dan Pasal 505 KUHPerdata ditentukan kedalam benda yang bertubuh dan tidak bertubuh, serta benda yang bergerak dan tidak bergerak, dan dalam penjelasan Pasal 1 Undang-undang Nomor 42 tahun 1992 disebutkan bahwa jaminan fidusia merupakan hak jaminan terhadap benda bergerak baik yang berwujud maupun yang tidak berwujud. Dari kesimpulan di atas yang dimaksud kategori benda yaitu meliputi suatu barang dan juga hak, barang tertuju pada benda yang memiliki wujud dan hak tertuju pada benda yang tidak memiliki wujud. Berdasarkan dari sifatnya maka hak terhadap merek dikategorikan sebagai hak kebendaan yang bergerak yang tidak berwujud. Berdasarkan ketentuan - ketentuan Hukum di atas semestinya Hak atas Merek dapat digunakan sebagai objek jaminan untuk memperoleh sumber pembiayaan.

\section{DAFTAR PUSTAKA}

Agniya Anggraeni, Hak atas merek sebagai jaminan Perusahaan ; dlam pelaksanaannya di Indonesia, Amerika Serikat, China, Inggris dan Singapura “ Tesis FH UI" (Jakarta, 2015)

Andrea Tosato, Security Interest Over Intellectual Property, Journal of Intellectual Property Law \& Practice vol 6 No 2, 2010, 9394

Darji Darmodiharjo dan Shidara, 2008, Pokok-pook Filsafat Hukum, Gramedia Pustaka Utama, Jakarta

J. Satrio, 2002, Hukum Jaminan dan Hak Jaminan Kebendaan. Cet ke -4 Bandung, Citra Aditya Bakti

Rachmadi Usman, 2011, Hukum Kebendaan, Sinar Grafika, 
Jakarta

Riduan Syahrani, Seluk Beluk dan Asas - asas Hukum Perdata, 1981, Alumni Bandung

Sri Mulyani, Pengembangan Hak Kekayaan Sebagai Collateral (Agunan) untuk mendapatkan Kredit Perbankan di Indonesia, Jurnal Fakultas Hukum UNTAG, 2001, Semarang, Hlm 569

Sri Mulyani, Realitas Pengakuan Hukum Terhadap Hak Atas Merek Sebagai Jaminan Fidusia pada Praktik Perbankan di Indonesia, Jurnal Fakultas Hukum UNTAG, Vol. 11 No. 2 edisi April 2014, hal 135-148

Soebekti, 2001, Pokok-pokok Hukum Perdata, Internusa, Jakarta

Sri Soedewi Masjchoen Sofwan, 1975, Hukum Jaminan di Indonesia Pokok-pokok Hukum Jaminan dan Jaminan Perorangan, Liberty, Yogyakarta

Sudargo Gautama, 1990, Segi-segi Hukum Milik Intelektual, Eresco, Bandung

Suyud Margono, 2011, Hak Milik Industri : Pengaturan dan Praktik di Indonesia, Ghalia Indonesia, Bogor

Tan Kamelo, 2006, Hukum Jaminan Fidusia : Suatu Kebutuhan yang Didambakan ( edisi Revisi), Alumni Bandung

Titik Triwulan Tutik, 2010, Hukum Perdata dalam Sistem Hukum Nasional, Kencana, Jakarta

Vennatia Sri Hadiarianti, 2015,
Memahami Hukum Atas Karya Intelektual, Grafindo, Jakarta Vennatia Sri Hadiarianti, 2015, Memahami Hukum Atas Karya Intelektual, Grafindo, Jakarta 